\title{
Capital Structure of Innovative Companies in BRICS Countries
}

\section{Elettra Agliardi}

M. Phil, PhD in Economics, Full Professor at the Department of Economics,

ORCID

E-mail: elettra.agliardi@unibo.it

University of Bologna, Italy

\author{
Anton Krupin \\ Graduate from bachelor's program «Economics», \\ ORCID \\ E-mail: akrupin@nes.ru
}

NRU HSE, Moscow, Russia

Journal of Corporate Finance Research, Vol. 13, No. 3, pp. 71-93 (2019)

DOI: https://doi.org/10.17323/j.jcfr.2073-0438.13.3.2019.71-93

Received 8 April 2019 | Peer-reviewed 5 June 2019 | Accepted 3 September 2019 


\section{Capital Structure of Innovative Companies in BRICS Countries}

\section{Abstract}

This article aims to identify the main business and economic determinants of capital structure in a sample of innovative companies from BRICS countries.

We achieve this by presenting a comparative analysis of 1,437 high-tech and 1,485 non-innovative companies in the pharmaceuticals, electronics, IT, and telecommunications sectors between 2008 and 2015. We conduct a regression analysis using a significant number of variables, such as profitability, size, proportion of tangible assets, and growth potential. The highlighted parameters are then examined in order to identify the characteristic features displayed in the capital structure of innovative firms.

Our results indicate that the following company characteristics are relevant in determining capital structure: information asymmetry costs (those which are associated with the unique activities of innovative companies), high growth potential generated by the availability of network effects, a high innovative applicability, low marginal and transport costs, and a high proportion of intangible assets. Moreover, we found that there is a distinct difference in the capital structure of companies as they vary in levels of innovation. An innovative company's proportion of intangible assets has a multidirectional effect on the debt amount. The potential for growth is also a significant factor which has a predominantly negative effect on the level of an innovative company's financial leverage. Levels of borrowing are overall lower for innovative firms.

Our major conclusion, drawing from the results above, is that innovative companies in BRICS countries use relatively little debt in the case of high growth potential. This indicates a general need to overcome the information asymmetry challenge in order to increase the growth rates of individual companies.

The scientific novelty of this analysis relates most strongly to the broadness of scope of our investigation, the focus on BRICS countries specifically, and the applicability of its conclusions in wider business and economic contexts. The breadth of data from a wide range of companies and sectors (both innovative and non-innovative), and the high number of companies utilized in the study, lend our evaluation an undeniable credibility within its scope, especially where it upholds similar conclusions in related literature of narrower focus. As a corollary to this, it may be conceivably asserted that these results are not merely applicable to individual companies, or even sectors of the economy, but due to their wide field of origin, they can have economy-wide implications on business and financial strategies.

Key terms: innovative companies, capital structure, pecking order theory, trade-off theory, sectoral specificities of companies, growth potential, intangible assets, equity and debt capital

JEL classification: G30, G32 


\section{Introduction}

The $21^{\text {st }}$ century economy is based on knowledge, and information has become a priority. It is safe to say that currently, knowledge in all its forms plays the most essential role in the process of economic development. Those countries which are capable of creating and effectively applying various kinds of knowledge have great potential for development, and companies that effectively and widely use new knowledge are a step ahead of their competitors. Innovation is a manifestation of new knowledge. At the macro level, innovations are a major factor in a country's economic growth. At the micro level, innovations allow companies to increase their performance and produce new products and services through the application of new technologies, materials and processes. However, it is difficult to assess the significance of innovations at the macro level without taking into account their role at the micro level of companies, as they also play a significant role in influencing the performance of firms.

One of these performance indicators is the company's capital structure - the debt-to-equity ratio in the cost of its capital. The capital structure is one of the key performance indicators of the company, as it allows evaluation of the current state of the company, its financial stability and future development prospects. In turn, a study of the capital structure determinants allows us to understand how a company makes a decision about debt formation, i.e. how a company controls its amount of debt.

The purpose of this paper is to investigate whether more innovative firms make different financing choices compared to less innovative firms. While there are already some contributions in the literature examining the ways in which innovative firms are distinctive in various aspects of their organization (for EU and US data in particular), the uniqueness of our study is that we perform this research on a sample of BRICS countries data. We provide evidence on innovation and financial structure from a panel of BRICS companies over the period 20082015 and add to the empirical literature on the nature of financial choices made by high-tech or innovative firms.

\section{Literature review}

Once the foundations of the capital structure theory were laid, a number of authors adopted an approach of testing the relevance of the pecking order and trade-off theories on real data at the national and international levels. Arguably the most significant research of this sort is the work by G.R. Rajan and L. Zingales [1], in which the authors conduct a comparative analysis of companies from G-7 countries. The authors come to the conclusion that it is difficult to determine in developed markets which of the capital structure theories provides a better reflection of the companies' behavior, since the prerequisites of both theories partially manifest themselves in the real data and do not contradict each other. Similar results were obtained individually for the United States [2], the UK [3], as well as for several developing countries [4].

Some authors came to more definite conclusions, in confirming the validity only of the pecking order theory in countries such as India [5] and Spain [6]. Conversely, some studies confirmed the trade-off theory for companies in Turkey [7] and South Africa [8].

Another area in which the capital structure theory has developed is the study of sectoral specificities of companies that may affect the level of a firm's debt. One of the first of such first studies is the work by M. Bradley et al. [9] which studies the average debt level of 851 American companies over a 20 -year period (and where the companies sample is divided into 25 different industries). The authors conclude that sectoral affiliation is a significant factor, which explains about $54 \%$ of the differences in the debt level among companies.

M. Talberg et al. [10] directly test the hypothesis on the relevance of a company's sectoral affiliation for the debt-to-equity ratio. Through a general regression analysis of all industries, and further study of each industry separately, the authors have come to the conclusion that this division is justified. In doing so, they confirm the need to take into account the sectoral affiliation of the company when studying its capital structure. However, the 2008 study also provided some equally relevant conclusions for the present article. First, M. Talberg et al. noted that companies affiliated with the IT sector have a lower level of debt than other firms under study from industries such as construction, food and drink production, etc. Second, individual regression for IT companies has the lowest explanatory power (the lowest R2) among all industries, while being high at the $1 \%$ interval. The authors clarify that this result may be associated with a relatively large share of "emissions" among IT companies, but at the same time it may mean that the basic model used in the article does not adequately reflect the specifics of the activities of these companies compared to firms from other sectors. The information technology sector traditionally belongs to innovative industries. In view of the meaningful role of innovation in the modern economy, it is necessary to conduct a more thorough analysis of high-tech ${ }^{1}$ companies in order to address the issue of the significance of the differences in their capital structure with firms from other sectors of the economy.

To carry out such analysis, it is necessary to identify the principal features of innovative companies that distinguish them from other firms, which, in turn, is impossible without an understanding of the very concept of "innovation". The contemporary approach to the concept is given in the "Guidelines for Collecting and Interpreting Data on Innovation", (otherwise known as 'the Oslo Manual'), a methodological document of the Organization for Economic Cooperation and Development (OECD) 
adopted in 1997. This document categorizes innovations into products and processes, as well as by the extent of innovativeness of changes in each case.

Thus, it may be concluded that an innovative company is a company that regularly (at least once every three years [11]) carries out one or several innovative activities, and it is important to note that the result of these activities should be economically significant. This means that innovation must be introduced into production or commercialized in some way. Abstract knowledge or the creation of a new product and process is not seen as an innovation before it is embedded in the production process of a company. Therefore, innovation must be inextricably linked with the main activity of an innovative company.

It is necessary to determine the features of innovative companies that may affect the equity-to-debt ratio. To accomplish this task, we make reference to previous studies which focus on the capital structure of firms in the innovation sector.

One of the first studies aimed at studying the capital structure of innovative firms was based on the sampling of small non-public IT companies in Ireland [12]. The authors state that one of the most significant features of small innovative companies is that they are characterized by the information asymmetry challenge, which arises for several reasons. First, due to the very essence of innovative activities aimed at creating new or improving existing products and processes, people directly involved in the company's work (and who are aware of the features of its activities) possess an understanding regarding the future success of certain innovation projects that the company is working on. For external market participants, and investors in particular, the question of the potential of a company can go unanswered, because the market may not have analogues of the innovation being developed. Therefore, an objective assessment of the innovative company's capabilities by an external investor appears to be difficult. Second, for small companies there is often insignificant public information, both of a financial and non-financial nature, which also turns them into a kind of "black box". Both of these reasons lead to the fact that, without sufficient understanding of the peculiarities of an innovative firm's activity, it is difficult for investors (particularly banks), to identify which projects are attractive investments and which do not have high potential. This has led to situations where, if faced with the need for external finance, small innovative companies have to pay higher loan rates as compensation to the bank for the risk. The alternative is that they will not to receive outside support at all if bank estimates of the adverse selection costs are too high.

In their work, T. Hogan and E. Hutson argue that the feature of innovative companies noted by them has a certain impact on the capital structure of these firms. High levels of borrowed capital, or the total lack of opportunities to attract capital, leads to a situation where small innovative companies have to finance their activities primarily from their own resources, and their debt has remained low. Furthermore, the authors state that this conclusion is more consistent with the pecking order theory than the trade-off theory, because the costs of information asymmetry force innovative firms to rank the sources of funding for their activities by the criterion of accessibility, thus disregarding the costs or benefits associated with the formation of an additional debt unit.

The study based on data about small companies in Finland [13] also proves that firms operating in the information and communication technology sector have lows levels of debt. Moreover, the authors of this work include in their analysis the expenses of companies for research and development (R\&D) which they consider to be the most important indication that the company is systematically engaged in innovative activities. They argue that R\&D expenses generate high growth potential of tech companies, because the more money that is invested in developing a new product or improving the existing one, the higher the probability will be of successful market entry in the future. Moreover, there are certain factors that are particularly acute in the areas of information and communication technologies which enhance the impact of growth potential on the capital structure of companies. These include:

- network effects (externalities) availability in the sector - which means that each new user of a product or service is capable of positively influencingthe usefulness of other users. Thus, for example, each new user of the telephone network or the Internet increases the value of other subscribers, as their opportunities to communicate with other people expand. If such a network effect "works" for a certain innovation, then the growth potential of the company increases dramatically;

- high applicability of innovations, which arises due the fact that the bulk of innovations in the information and telecommunication technology sector are aimed at improving the products used in their respective industries [14];

- the availability of fixed costs of entry into a number of areas of the information and telecommunication technology sector, as well as a low level of marginal and "transport" costs due to the nature of the product itself.

However, the theory says that growth potential negatively affects the level of a company's debt due to the fact that it is intrinsically linked to the costs of underinvestment [15; 16]. These costs mean that a company that highly evaluates its development opportunities will tend to borrow less since, all other things being equal, with debt liabilities, it will cost less in the future than in a situation where the debt is zero. Therefore, we can conclude that due to the nature of their activities innovative companies have high growth potential which, in turn, reduces the motivation to use debt instruments.

The next specific feature of high-tech firms is that the intangible part in the structure of their assets amounts to a 
larger share than in non-innovative companies [17]. This feature also negatively affects the capability of innovative companies to raise borrowed capital for the following reasons. First, intangible assets very rarely act as debt security. This is primarily due to their uniqueness since, for instance, a new invention, patent or special software may have no analogues on the market or be relevant only for the purposes of a particular company, and therefore the intangible asset value may be undetermined. Second, the same feature of uniqueness in the face of financial difficulties contributes to a faster loss by an intangible asset of its value which increases the expected bankruptcy costs [18]. Third, intangible assets in high-tech companies may also appear in the form of knowledge contained in the human capital of the company's employees [19]. This means that in the situation where an employee resigns or leaves the company, the firm may face serious challenges.

All of the above works note the following: the innovative activity of companies can lead to the fact that their debt level will be low due to the information asymmetry costs, high growth potential and a specific structure of assets. However, some studies have obverse arguments. Thus, E. Bartoloni [20] states that the need for external funding of the company's activities increases in line with the extent of innovation activity, and this conclusion remains relevant regardless of the company size. It has also been proven that for fast-growing companies, the problem of inadequate revenues to finance and maintain their development is an urgent one [21]. Consequently, it is impossible to state unequivocally how the features of innovative companies influence their capital structure.

It should be noted once again that the above works on the capital structure of innovative companies [12;13] focused on the study of small companies, but they have not studied public firms. This is notable, as in most cases public companies have great financial potential in terms of investing in the development and improvement of products, processes and technologies, and therefore play an important role in the process of generating innovations. This gap is filled with the work by P. Castro and M. Tascón [22], who study the capital structure of public European companies. The authors argue that the information asymmetry challenge, which is vividly manifested for small companies, also directly influences the position in the debt capital market of listed firms, despite their obviously greater openness and transparency for market participants. The distinctive feature of their study is also the fact that the work provides a comparison of the debt levels in hightech and non-innovative firms at different stages of the life cycle. This approach suggests that innovative companies have a lower level of debt, and this observation is true at all stages of the company life cycle. Furthermore, the authors of the work confirm the hypothesis that growth potential is a significant factor influencing the level of the company's debt. The nature of the influence of a range of other explanatory variables shows that the behavior of innovative companies is more consistent with the pecking order theory, which also coincides with most previous studies.
And finally, another work dealing with the data of UK public companies reveals a non-linear relationship between the firm's innovative activity (measured as R\&D expenses) and its debt level [23]. The authors of this article argue that the companies which have positive R\&D costs use more borrowed capital than companies with a 'zero' level of these costs. As for firms with positive R\&D costs, the volume of their borrowing decreases with the growth of this cost item. The findings obtained in the work may indicate that public high-tech companies use more borrowed funds than non-innovative firms. In turn, the higher the level of a company's innovative activity, the lower the level of borrowings it exhibits. This conclusion, on the one hand, supports the results of those studies concerning the negative relationship between innovation activity and debt. On the other hand, it contradicts the arguments of other authors that innovative companies have less borrowed capital. It follows that in the literature there is no unambiguous understanding of the relationship between innovation activity and debt, especially for developing countries' markets.

Thus, based on the results of various works focused on the study of the capital structure of innovative companies, a number of hypotheses can be made that will be tested in the future.

The process of choosing the capital structure for innovative companies in the BRICS countries is significantly different from the process of choosing the capital structure for non-innovative companies.

The debt level of innovative companies in the BRICS countries is lower than in non-innovative companies.

The decision regarding the determination of the capital structure of innovative companies is more consistent with the pecking order theory than the trade-off theory.

The proportion of intangible assets and the growth potential of the company adversely affect the level of borrowed capital.

\section{Methodology of the Study}

The most common approach to determine the innovativeness of a company is the sectoral characteristic. So, J. Francis and K. Schipper [24] define the following four sectors as innovative: information technologies, electronics, pharmaceuticals and telecommunications, asserting that in these industries intangible assets play the greatest role, and the nature of their activities can be considered innovative. The authors use the SIC standard industrial classification which assigns a three-digit code to each industry. It is on the basis of this system of codes that the final determination of the innovative nature of the activities of a company takes place. It should also be noted that the authors use a similar approach to determining lowtech companies, which is necessary in the course of their research. This decision regarding the high-tech status of the company as a sectoral affiliation has been developed in the works of other authors who have made the selec- 
tion of industries under SIC in more detail, expanding the list of industries in which companies fit the definition of innovative companies [22; 25].

The present article has applied this particular second method of selecting innovative companies. Such decision is, firstly, due to the availability of a number of described shortcomings of the first method, which may lead to the inclusion in the analysis of companies that are not innovative in nature or, conversely, the disregarding of those high-tech firms whose reports do not provide information on the R\&D costs. Secondly, the selection of innovative companies based on the standard industrial classification appears to be more uniform and simple to use. Furthermore, it is used by a number of authors, and also does not contradict other research studying the behavior of hightech companies.

Thus, the analysis includes public BRICS companies affiliated with the following sectors: pharmaceuticals, electronics, information technology, and telecommunications. More detailed information on the SIC-codes included in the review is provided in Appendix 1.

It is also notable that, for research purposes, there is a need for sampling of companies from non-high-tech industries. The criterion for their sampling is similarly formed on the basis of the SIC-codes, and their list is taken from the work [25] and is also given in Appendix 2.

The whole study can be divided into two main stages: at the first stage, the analysis of differences in the capital structure between two samples consisting of innovative and non-technological companies was carried out. This step is necessary to test hypotheses 1 and 2 , since it is at this stage that it will be determined whether it is possible to describe the process of capital structure formation by companies different in the degree of innovativeness by one regression model, or if the models should differ for various firms. At the second stage, the model will be increasingly complicated in order to study the capital structure of innovative companies more closely. At this stage, the remaining two hypotheses will be tested and conclusions will be made regarding the effect of various determinants on the debt level in high-tech companies.

We are going to take a detailed look at each stage of the study, and to start with, we describe the basic model which will serve as the basis for the entire regression analysis. This model was formulated by G.R. Rajan and L. Zingales in 1995 [1] when they studied the differences in capital structure between companies in G-7 countries. The model which will be described later is used in this article's analysis for several reasons. First, it is used as the basis in most studies focused on the analysis of companies' capital structure, regardless of sectoral, national, or other characteristics. This is because the determinants included in the model reflect the key characteristics of the company that affect its debt level, so most of the coefficients are significant in any study. Second, this model reflects universal characteristics essential for any company, such as size, profitability, etc., thereby ensuring the applicability of the model for samples consisting of various companies, and making it possible to compare these samples with each other.

The dependent variable in the described model is the ratio of the value of the company's borrowed capital to its equity. Equity capital is calculated in two forms - as a market and balance value. This approach to the definition of the explanatory variable is maintained in all such studies, the varieties of debt just change (for instance, long-term and short-term). Turning to the studies already considered in the literature review, some authors use in the analysis the ratio of long-term debt to the book value of assets [22], while others use the total liabilities while maintaining the balance sheet approach to determining equity capital $[13 ; 23]$. Based on this, we will focus on using the ratio of total liabilities to the book value of the company's assets (Leverage) as a dependent variable.

Herewith we will examine the set of explanatory variables of the basic model which are also defined as determinants of the capital structure, and which justify expectations regarding the influence of these factors on the size of the company's debt.

Profitability of the company (Prof), calculated as the ratio of a company's earnings before interest and taxes (EBIT) relative to its total net assets. Capital structure theories interpret the influence of this factor on leverage in different ways. According to the pecking order theory the more profitable a company is, the larger the amount of internal resources it has to finance its activities, and the less need it has of borrowed funds, whereas the trade-off theory states that more profitable firms can borrow funds on more favorable terms and, therefore, increase debt, since the bankruptcy probability is small.

The findings of various studies regarding companies' capital structure comprise the prevailing uniformity of outlook regarding the impact of profitability on leverage, and this impact is seen to be negative. Whether it is a study of the markets of G-7 countries [1], Russia [26], China [27] or India [4], the effect of the variable always remains significant and negative. In the case of innovative companies, it can be assumed that the effect predicted by the trade-off theory will be less significant than the information asymmetry challenge. Therefore, it can also be assumed that the negative effect of this variable on the debt level will also be less significant. Note that this assumption is supported by the findings of the fundamental work on the theme.

Size of the company (Size). There are two main approaches to the calculation of this variable. First, it can be calculated as the natural logarithm of the total assets value [22], and second, as the natural logarithm of the amount of the sales proceeds [1]. In this article, the choice has been made in favor of the second method, since this variable shows more stable and significant results in the regression analysis (which is given below).

Based on the theory, it is difficult to clearly assume the nature of the impact of the company's size on the level of its debt. 
Table 1. Directions of the core variables effect

\begin{tabular}{|c|c|c|c|c|}
\hline Variable & Value & Pecking order theory & Trade-off theory & Expected effect \\
\hline Prof & Profitability & - & + & - \\
\hline Size & Company's size & - & + & $+1-$ \\
\hline Tang & Proportion of tangible assets & - & + & + \\
\hline $\mathrm{MtB}$ & Market-to-book value & $+/-$ & - & - \\
\hline
\end{tabular}

Source: drafted by the author.

On the one hand, the size of a firm may act as a reverse proxy variable for the bankruptcy probability, thereby predicting a positive impact on the amount of borrowings. On the other hand, assuming that a larger company has more accumulated assets, it can be suggested that it will tend to use its own equity.

The two hypotheses proffered above are supported by various studies of the capital structure of high-tech companies, where the coefficient value with the variable depends on the model specification [20] or the company's life cycle [22].

Tangible assets (Tang) is the ratio of the PP\&E book value to the total assets of the company. The variable reflects the proportion of tangible assets in the company and is the inverse indicator of the proportion of intangible assets. Based on the trade-off theory, it can be assumed that this ratio will have a positive effect on the debt level, because tangible assets can serve as collateral for the loan and, furthermore, their cost is more stable over time, in contrast to intangible assets. The pecking order theory, on the contrary, predicts that with an increase in intangible assets, the need for their funding grows, and due to the high information asymmetry, the use of equity capital can be extremely costly [28]. In general, taking into account the specifics of innovative companies, it can be suggested that any significant expansion in PP\&E will have a positive effect on the company's sustainability in the minds of borrowers, thereby contributing to an increase in borrowing.

The company's market-to-book ratio $(\mathrm{MtB})$ is a variable that is recognized in the literature as a proxy for the company's growth potential, and therefore, based on the findings of the special growth potential significance for the innovation sector, the negative relationship between the factor and the debt level is assumed.

The overall conclusions regarding the expected effect of the basic model factors are given in Table 1 .

The objective of the first stage of the study is to identify differences in the capital structure of non-innovative and high-tech companies. For these purposes, in addition to analyzing descriptive statistics, first, a dummy variable (TechDummy) will be applied which is responsible for representing a company's affiliation with the innovation sector. The significance of this variable will make it possible to note that the innovativeness of the sector is indeed an important factor in explaining the company's capital structure. Second, a separate analysis will be carried out for innovative and non-innovative companies, and then the Chow test (in line with the approach used by P. Castro and M. Tascón [22]) will be conducted, which will make it possible to determine whether it is necessary to describe these companies separately, or whether in fact differences in the influence of key determinants of capital structure between companies are insignificant. Thus, the regression in the first stage of the study is presented as follows:

$$
\begin{aligned}
& \text { Leverage }=\beta_{0}+\beta_{1} \cdot \text { Prof }+\beta_{2} \cdot \text { Size }+ \\
& +\beta_{3} \cdot \text { Tang }+\beta_{4} \cdot \operatorname{MtB}+\beta_{5} \cdot \text { TechDummy }+\varepsilon_{\text {it }} \text {. } \\
& \text { Methodology for Analysis } \\
& \text { of the features of the Features } \\
& \text { of Innovative Companies }
\end{aligned}
$$

The second stage of the study is focused on more detailed examination of the determinants of the capital structure of only innovative companies. To perform a detailed analysis, it is necessary to expand the list of variables used in the regression, some of which will complement the standard set of factors commonly taken into account in studying the capital structure, while others reflect the features of particularly innovative companies.

The first supplementary variable is the lagged profitability value, which is one year behind (LProf). It is assumed that a potential borrower is able to form his opinion on the financial stability of a company based on previous indicators of its profitability, because the higher this parameter is, the lower the expected bankruptcy probability. In this regard, a positive relationship is expected between the lagged profitability value and the level of the company's debt.

The next variable is a non-debt tax shield (NDTS) value which is calculated as the ratio of the value of depreciation to the company's total assets [2]. The meaning of this variable is that any company charging depreciation on its $P P \& E$ reduces the size of the taxable base by the amount of these charges. For that reason, a so-called non-debt tax shield arises, which in this case arises for a reason unrelated to the payment of interest on loans. It can be assumed that the larger the non-debt shield value, the less incentives to form a debt a company will have, because the benefits of a debt shield are replaced by those of a non-debt one.

In their work, S. Titman and R. Wessel [2] argue on the shortcomings of this indicator, indicating that it may not take into account the intangible part of the compa- 
ny's assets. Since this article deals with the behavior of innovative companies, firstly, the amortization amount is calculated as the sum of deductions for both types of assets, and secondly, after P. Castro and M. Tascón [22], it is necessary to include into the analysis a separate variable calculated as the ratio of the intangible assets amortization to the total amount of amortization charges (IntAmort). This determinant will make it possible to consider the impact of intangible assets on the capital structure of innovative companies from the opposite perspective to that of the variable responsible for the proportion of tangible assets. Based on the theoretical assumptions, the negative impact of the debt level can be suggested.

The next common variable, already mentioned in the previous discussion, reflects the tax benefits that the company receives, forming a debt (TaxSh). Such benefit arises when the firm reduces the amount of taxable income by the amount of payments on its financial liabilities. This indicator is calculated as the ratio of the profit tax value paid by a firm to its before-tax profit [26] (this, in fact, constitutes the effective tax rate). It is expected that the effect of this factor will have the opposite direction regarding the non-debt tax shield value, since by increasing the amount of borrowed capital the firm reduces the amount of obligatory tax.

In considering the challenges faced by innovative companies, it should be noted that information asymmetry is one of the most pressing and most difficult obstacle to overcome. However, there are two indicators inherent in each company which act as proxy variables for the bankruptcy probability, and, therefore, are capable of indirectly reflecting the safety of investing in a particular company. One of these indicators - the company's size - was described in detail as part of the basic model of this study, while the second indicator is the company's age (Age), acting as one of the criteria for the company's reputation [28] and the risk associated with it [29]. It is believed that the costs associated with the debt generation are higher for companies with lower standing [20], and therefore it can be assumed that a longer number of years of company existence will have a relatively more positive effect on its debt level. In our article, 'age' is defined as the logarithm of the difference between the observation year and the year of the company's establishment.

The block composed of the following variables represents three different approaches to describing a company's growth potential, which, as follows from theoretical assumptions, should play a significant role in describing the company's decision-making process regarding its borrowed capital value. The first variable is a part of the basic model and is the ratio of the company's capitalization to the book value of its assets. The remaining two variables will only be included in the final analysis of this analysis. One of them is the ratio of capital costs to the company's total assets (GrOpp) [2]. The goal of including this indicator into the analysis is to control the growth potential that is generated through investments not in research and development, but in PP\&E which can improve production performance, product quality or increased production capacity. These improvements certainly increase the development potential of the company, but they are not directly related to its innovative activity. However, the assumption regarding the influence of this factor on leverage is entirely based on theoretical conclusions about the costs of underinvestment in the future, and therefore a negative relationship between this variable and the debt level can be assumed.

And finally, the last proxy variable for growth potential is the level of $R \& D$ expenses $(\mathrm{RnD})$, which in a number of studies acts as the key indicator of the company's innovative activity. There are two main ways of calculating this indicator - as the ratio of $\mathrm{R} \& \mathrm{D}$ costs to sales revenue [2; $13 ; 23]$ and as the ratio of these costs to the company's asset value [22; 30]. It is difficult to substantiate in theory the correctness of using a particular method to calculate the variable, however, based on the results of the regression analysis (which is carried out at the next stage of work), it has been decided to use the ratio of R\&D costs to sales revenue in the analysis, since this option of the variable appeared to be more significant.

Based on the above theoretical prerequisites, it is difficult to assume the nature of the impact of the level of R\&D costs on the amount of financial liabilities of a company. Nevertheless, much of the studies reveals the negative relationship which is associated by the authors with the growth potential generated by R\&D costs [13] and the intangible nature of the assets that are the product of these investments [31]. However, at the same time, other studies reveal a non-linear relationship, as in the work by [23] (the essence of non-linearity is described in the literature review). Against this background, it should be assumed that $R \& D$ expenses will contribute to reducing the company's debentures.

The last block of variables included in the analysis consists of dummy variables responsible for the company's affiliation with one of the countries from the list under examination: Brazil, Russia, India, China or South Africa. To avoid the issue of full multicollinearity, four dummy variables have been included in the model, and the fifth is taken as the base one.

This model specification will make it possible not only to assess the impact of standard factors on the capital structure of innovative companies, but also to account for their features. Furthermore, such a set of variables will allow for the determination as to whether the pecking order theory is more preferable for high-tech companies. This is because the analysis includes variables, the direction of influence of which is predicted by the theory, andthe regression analysis allows for the drawing of a conclusion as to whether the expectations coincide with the actual situation, and, therefore, whether hypothesis 3 is supported. In addition, this model specification makes it possible to formulate a conclusion regarding the influence of the growth potential and the structure of the assets of innovative companies on their debt amount, which will be a test of hypothesis 4 . 


\section{Empirical Analysis of the Capital Structure of the BRICS' Innovative Companies}

\section{Information base of the study}

The Capital IQ has become the base source of data on the financial performance of companies. The selection of companies was performed using the below criteria (with each company in the sample possessing all charateristics): being a public joint-stock company, since only this type of company is required to disclose data on its activities;

- being located in one of the BRICS countries: Brazil, Russia, India, China or the Republic of South Africa;

- holding affiliation with the industry defined in accordance with the SIC coding. The full list of codes used and their respective industries are given in Appendices 1 and 2;

- $\quad$ having a positive value of total proceeds. The criterion has been applied with a view to excluding non-operating companies from the analysis.

As for the time frame of the study, the ten-year period from 2007 to 2016 was initially covered, but it was modified to reflect the period from 2008 to 2015 , due to the fact that in 2007 there were a large number of gaps in various company performance indicators, as well as on the date of data collection, and most companies have not yet submitted their financial statements for 2016. Thus, this work covers an eight-year period, which is sufficient ${ }^{2}$ to conduct a study of the capital structure, especially in emerging markets.

As a result of applying this list of criteria, a sample of 1437 high-tech and 1485 non-innovative companies was obtained, which was transformed into a balanced panel through the Stata $13^{3}$ program. But then, the observations were filtered in two stages in order to improve the quality of the studied data. At the first stage, companies were excluded from consideration, for which more than half of the observations for such indicator as the book value of total assets are non-available. This step was taken due to the fact that most of the variables used in the regression analysis are normalized to the asset value, therefore the non-availability of a significant part of observations for this indicator in the company makes its consideration inappropriate At the second stage, data analysis was carried out, including consideration of the maximum and minimum values for all indicators used, as well as the value of standard deviations. The result of this analysis was the exclusion from the sample of those observations for which a significant deviation of the indicator from its average value was found, which could distort the subsequent results of the regression analysis. The outcome of these adjustments was that the number of innovative companies being studied was reduced to 939, while the number of non-innovative firms under consideration amounted to 659 .

The distribution of companies by country is shown in figures 1 and 2 . The figures show that the majority of companies from all sectors are concentrated in China, while the remaining countries have approximately equal shares in the sample. Of course, this distribution cannot be considered optimal, however, in other studies there is a similar disparity (for example, [22]), which is not considered by the authors as an obstacle to further analysis.

Figure 1. Distribution of innovative companies by country Innovative Companies

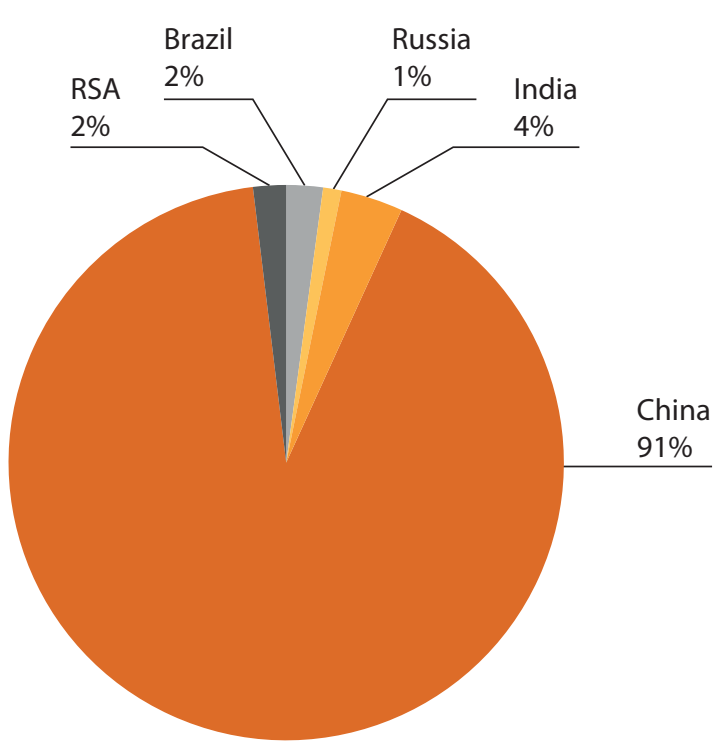

Figure 2. Distribution of non-innovative companies by country

\section{Non-innovative Companies}

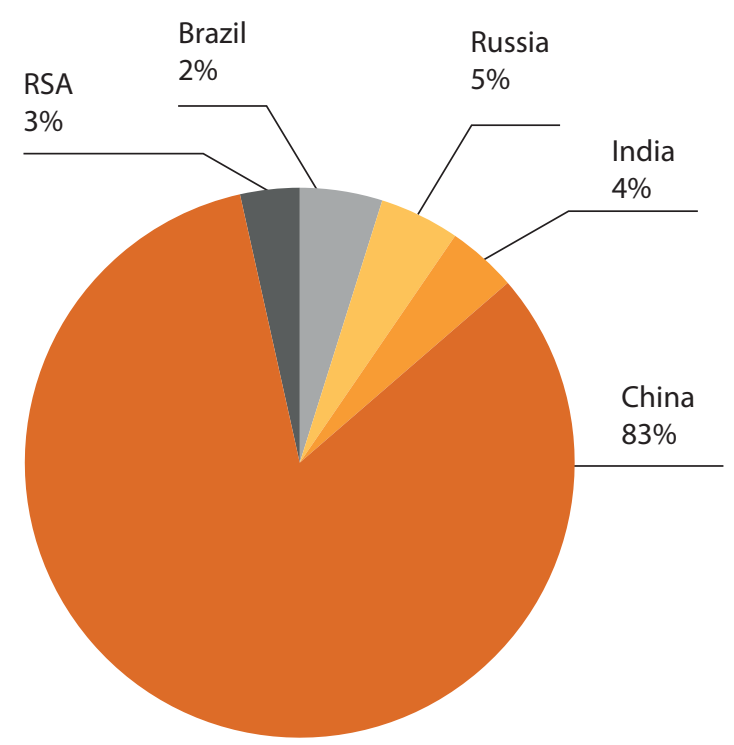

\footnotetext{
${ }^{2}$ For reference, I. Ivashkovskaya and M. Solntseva [26] use the six-year period for Russia, J. Chen [27] the six-year period for China, E. Bartoloni [20] the eight-year period for Italy and P. Castro et al. [22] - the 13-year period for a number of European countries.

${ }^{3}$ The follow-up regression analysis will be performed using this program.
} 
Table 2. Descriptive statistics of the core variables for innovative companies

\begin{tabular}{|c|c|c|c|c|c|}
\hline Variable & Obs & Mean & Std. Dev. & Min & Max \\
\hline Prof & 6696 & 0,10 & 0,09 & 0,01 & 1,42 \\
\hline Size & 6757 & 4,94 & 1,54 & $-4,13$ & 10,88 \\
\hline Tang & 6696 & 0,21 & 0,15 & 0,01 & 0,98 \\
\hline $\mathrm{MtB}$ & 6708 & 15,5 & 29,91 & 0,07 & 299,45 \\
\hline Debt & 6696 & 0,13 & 0,17 & 0,00 & 1,47 \\
\hline
\end{tabular}

Source: drafted by the author.

Table 3. Descriptive statistics of the core variables for non-innovative companies

\begin{tabular}{|c|c|c|c|c|c|}
\hline Variable & Obs & Mean & Std. Dev. & Min & Max \\
\hline Prof & 4782 & 0,08 & 0,07 & 0,01 & 1,86 \\
\hline Size & 4833 & 5,73 & 1,79 & $-3,04$ & 11,82 \\
\hline Tang & 4782 & 0,35 & 0,20 & 0,00 & 0,98 \\
\hline $\mathrm{MtB}$ & 4792 & 8,46 & 23,61 & 0,01 & 283,42 \\
\hline Debt & 4782 & 0,24 & 0,18 & 0,00 & 1,74 \\
\hline
\end{tabular}

Source: drafted by the author.

\section{Results}

An examination of these results shall commence with a comparison of the basic model for high-tech and non-innovative companies, given in Tables 2 and 3, respectively. Based on the data given, a number of conclusions may be drawn regarding the main characteristics of companies and their differences between sectors. First, innovative companies in the sample are more profitable than non-innovative firms, although the difference in this indicator is not so significant. Second, firms from different sectors are comparable in size, although non-innovative companies are on average larger. These two indicators show that companies with different levels of innovation activity have approximately the same average profile regarding size and profitability with very similar values of standard deviations of indicators, which means that comparable companies will be compared. This, in turn, ensures the objectivity of the findings that will be further refined.

The third feature of the sample is the fact that high-tech companies have a lower proportion of tangible assets. This fact is fully consistent with the theoretical premise that innovative companies use more intangible assets in their activities. The fourth finding is that the MtB variable is on average significantly higher for innovative firms. Since this factor is one of the proxy variables for growth potential, it can be concluded that descriptive statistics supports the assumption that high-tech firms have higher development opportunities.

Having obtained an overall perspective of the nature of the data being studied, we proceed to the first stage of the study, the essence of which is to test the significance of the differences between the effects of the basic model determinants on the capital structure of companies which differ in innovativeness. To achieve this goal, a basic regression was made on data from all companies included in the sample. The Debt is a dependent variable, and all factors, the descriptive statistics of which have been considered earlier, are explanatory. Furthermore, there is a dummy variable in the regression, which takes on the value of 1 if the company is recognized as innovative, and the value of 0 if not. The results of this regression are given in Table 4.

Based on the results obtained, it can be concluded that all the coefficients of the model are significant at the $1 \%$ level, as well as the regression model itself. The significance of the dummy variable makes it possible to support the hypothesis 1 , that the innovative nature of the company's activities has an effect on its debt level. To finally test this hypothesis, we make two separate regressions for hightech and non-innovative firms (without the use of a dummy variable), and then we carry out a Chow test, which will make it possible to determine whether the differences in the models made are significant. 
Table 4. The results of the basic model evaluation for three different samples

\begin{tabular}{|c|c|c|c|}
\hline Variables & Full sample & Non-tech & Tech \\
\hline Prof & $-0.230^{* * *}$ & $-0.237^{\star * *}$ & $-0.225^{\star * *}$ \\
\hline Size & $0.0186^{* * *}$ & $0.0190^{* * *}$ & $0.0180^{\star * \star}$ \\
\hline Tang & $0.313^{\star * *}$ & $0.333^{\star * *}$ & $0.290^{\star * *}$ \\
\hline MtB & $0.000507^{* * *}$ & $0.000632^{\star * *}$ & $0.000438^{\star * *}$ \\
\hline Tech_dummy & $-0.0477^{\star * *}$ & - & - \\
\hline Constant & $0.0383^{* * *}$ & $0.0282^{* * *}$ & -0.00131 \\
\hline Observations & 11472 & 4776 & 6696 \\
\hline $\mathbf{R}^{2}$ & 0.24 & 0.19 & 0.15 \\
\hline
\end{tabular}

${ }^{\star} \mathrm{p}<0.1 ;{ }^{* *} \mathrm{p}<0.05 ;{ }^{* *} \mathrm{p}<0.01$.

Source: drafted by the author.

The results of this stage, shown in Table 4, indicate the following: all regressors are significant regardless of the nature of the companies under consideration, and the direction of their effect on the level of debt in the company is also maintained. However, the explanatory capacity of the regression applied to non-innovative companies is slightly higher ( $\mathrm{R}^{2}$ is 4 points higher). This result may mean that the same set of factors explains the behavior of innovative companies regarding the generation of debt with less accuracy than it explains the behavior of firms not involving innovation activities.

Now the Chow test will be implemented, taking the null hypothesis of equality of the coefficients of the two equations and on the basis that there are 4 variables in the model, and the number of observations for the group of innovative firms is 6.814 (for the rest this figure is 4.849. The result of the test is that the observed F-statistics equals to 48.82 . As for the critical value, then for the $5 \%$-point of significance it is 2.21 . The observed value of F-statistics significantly exceeds the critical value, which implies that the test's null hypothesis is rejected. Based on the result obtained, it can be concluded that different samples should be described by different equations, which means that the decision-making principle regarding the generation of debt varies for companies differing in their level of innovation. This thesis suggests that hypothesis 1 of the study is thereby validated.

Now, having established that there are significant differences between the two described samples from companies with different levels of innovation, we can re-examine Tables 1 and 2, and note that the average observed level of debt of innovative firms is almost 2 times lower than the same indicator for non-innovative companies. In order to find out to what extent this difference is significant, we will perform Student's test for the equality of two means. It should be noted that the standard deviations for the Debt variable almost coincide for the two groups, there- fore, it is possible to run this test. Setting the null hypothesis of equality of means, we obtain the value of t-statistics at the point of 14.25 . At the same time, the critical value at the $5 \%$ point of significance is 1.96 , which makes it possible to reject the null hypothesis of this test. Thus, the Student's test states that the means of debt are different for two samples. This result, in turn, allows for the conclusion that the level of debt of innovative companies is lower than in other firms, and this is a confirmation of hypothesis 2.

Summing up the findings of the first stage of the study, it can be said that hypotheses 1 and 2 were confirmed. This means that companies engaged in innovative activities make a decision on the generation of debt differently from firms for which innovative activity is not typical. Furthermore, high-tech firms have, on average, lower levels of debt than companies from other sectors.

\section{Econometric Analysis of the Determinants of Innovative Companies" Capital Structure}

The first stage of the study has shown that the structure of innovative companies is significantly different from the capital structure of other companies, and therefore a thorough and in-depth analysis of the determinants affecting the amount of debt of high-tech firms is necessary.

We are going to start the analysis with a review of descriptive statistics of supplementary factors given in the methodological part of the work. As shown in Table 5, the effective profit tax rate, acting as a proxy variable for tax benefits, is on average $18 \%$. This value is entirely accurate, since in Brazil the profit tax rate is 30\%, in Russia - 20\%, in India $-30 \%$ (with a possible $20 \%$ tax deduction for R\&D expenses), in China - 15\% for high-tech companies, and in South Africa - 30\%. Given that Chinese companies make 
up most of the sample, the observed average value of the effective profit tax rate naturally increases due to higher rates in other countries. Moreover, the age of the average company for the sample is 15 and takes on a range values from 4 to 95 (the table shows the logarithm of age; the minimum value is rounded to zero by the program). This means that the companies that are completely different in the time period of the company's existence are analyzed both entrenched market players and firms that have recently entered it. It can also be noted that the $\mathrm{RnD}$ variable has a slightly smaller number of observations in comparison with other determinants. This fact can be explained by the fact that many companies do not show up the R\&D costs as a separate item in their financial statements.

We'll also look at the correlation matrix for independent variables given in Table 6. A number of features are included in this matrix. First, the relatively high correlation of the MtB variable with factors such as Prof and Size is indicated. This fact can be quite logically explained by the fact that, on the one hand, more profitable companies will naturally have a higher market value due to their attractiveness to market participants. On the other hand, larger companies (where size is defined as the log of sales) have a large amount of assets (the correlation of these indicators is more than 0.9 ), which leads to a decrease in MtB. In general, without taking into account the high correlation between the non-debt tax shield and the share of intangible asset amortization, which is natural owing to the principle of calculating variables, the low degree of interrelation between various factors can be noted.

Having made conclusions regarding the main characteristics of those determinants that will be used in the second stage of the study, we proceed directly to testing regression models. We'll start with making the Pooled model, and then compare it with more complex models with fixed and random effects.

Table 5. Descriptive statistics of supplementary variables

\begin{tabular}{|c|c|c|c|c|c|}
\hline Variable & Obs & Mean & Std. Dev. & Min & Max \\
\hline TaxSh & 6693 & 0.18 & 0.12 & 0.00 & 1.00 \\
\hline Age & 6063 & 2.70 & 0.71 & 0.00 & 4.55 \\
\hline $\mathrm{RnD}$ & 5601 & 0.06 & 0.07 & 0.00 & 0.99 \\
\hline NDTS & 6499 & 0.02 & 0.02 & 0.00 & 0.42 \\
\hline IntAmort & 6383 & 0.13 & 0.17 & 0.00 & 1.00 \\
\hline
\end{tabular}

Source: drafted by the author.

Table 6. Correlation matrix

\begin{tabular}{|c|c|c|c|c|c|c|c|c|c|}
\hline & Prof & Size & Tang & MtB & TaxSh & Age & $\mathrm{RnD}$ & NDTS & IntAmort \\
\hline Prof & 1,00 & & & & & & & & \\
\hline Size & $-0,17$ & 1,00 & & & & & & & \\
\hline Tang & $-0,08$ & 0,09 & 1,00 & & & & & & \\
\hline $\mathrm{MtB}$ & 0,45 & $-0,35$ & $-0,07$ & 1,00 & & & & & \\
\hline TaxSh & $-0,12$ & 0,13 & 0,03 & $-0,10$ & 1,00 & & & & \\
\hline Age & $-0,23$ & 0,27 & 0,05 & $-0,24$ & 0,09 & 1,00 & & & \\
\hline $\mathrm{RnD}$ & $-0,01$ & $-0,24$ & $-0,17$ & 0,06 & $-0,13$ & $-0,09$ & 1,00 & & \\
\hline NDTS & $-0,03$ & 0,12 & 0,49 & $-0,03$ & 0,04 & 0,01 & $-0,03$ & 1,00 & \\
\hline IntAmort & $-0,14$ & $-0,03$ & $-0,24$ & $-0,09$ & 0,01 & $-0,02$ & 0,15 & $-0,02$ & 1,00 \\
\hline
\end{tabular}

Source: drafted by the author.

The results of all three models are given in Table 7, however, before starting to interpret the results obtained, it is first necessary to determine which model is preferable in order to explain the choice of capital structure, and second, to test the selected model for potential issues such as multicollinearity, heteroscedasticity and autocorrelation.
To identify the most adequate model, we will run a series of tests that compare all three models in pairs with each other. We'll start with the F-test (integrated into the FE-model assessment procedure, so the result is not shown separately), the statistics for which is 11.66 with its critical value of 1.1 . 
Table 7. Regression models evaluation results

\begin{tabular}{|c|c|c|c|}
\hline Variables & Pooled & FE & $\mathbf{R E}$ \\
\hline Prof & $-0.226^{\star * *}$ & $-0.0799^{* * *}$ & -0.0238 \\
\hline LProf & $-0.0436^{\star * *}$ & -0.0109 & -0.0164 \\
\hline Size & $0.0180^{* * *}$ & $0.0340^{* * *}$ & $0.0242^{* * *}$ \\
\hline Tang & $0.333^{\star * *}$ & $0.226^{* * *}$ & $0.266^{* * *}$ \\
\hline $\mathrm{MtB}$ & $0.000455^{\star * *}$ & $0.000423^{\star * *}$ & $0.000406^{* * *}$ \\
\hline GrOpp & -0.0112 & -0.0317 & -0.0248 \\
\hline $\mathrm{RnD}$ & $-0.182^{\star * \star}$ & 0.0340 & $-0.0512^{\star}$ \\
\hline TaxSh & $0.0382^{\star *}$ & 0.00949 & 0.0103 \\
\hline Age & -0.00237 & $-0.0292^{\star * *}$ & -0.00463 \\
\hline NDTS & $-0.368^{* * *}$ & -0.0198 & -0.0917 \\
\hline IntAmort & $0.0212^{*}$ & $0.0328^{\star * *}$ & $0.0255^{* *}$ \\
\hline Constant & 0.00188 & -0.0331 & $-0.0422^{\star *}$ \\
\hline Observations & 4,120 & 4,120 & 4,120 \\
\hline $\mathbf{R}^{2}$ & 0.213 & 0.174 & 0.157 \\
\hline
\end{tabular}

${ }^{\star} \mathrm{p}<0.1 ;{ }^{* *} \mathrm{p}<0.05 ;{ }^{* *} \mathrm{p}<0.01$.

Source: drafted by the author.

This result suggests that in choosing between the Pooled model and the fixed effects model, preference is given to the second revision of the specification. To compare the Pooled model and the random effects model, we will perform a Breusch - Pagan test (Appendix 3), the test statistics of which states that the RE-model has a greater explanatory power. And finally, we'll compare the FE- and RE-models, using the Hausman test for this purpose (Appendix 4). Based on the results of this test, preference is given to the fixed effects model. The final result is that the most effective specification is a fixed effects model, while the Pooled regression is least preferred.

The next step to obtain the most optimal model is to test for various errors, the first of which may be multicollinearity. To test for this error, we'll calculate an indicator such as VIF. The results given in Table 8 suggest that the multicollinearity problem may be present in a fixed effects model, since several VIF values exceed the value of 4 , which is traditionally recognised as the maximum level. However, applying the same approach to pooled regression, it can be noted that for it there is not a single VIF value above the acceptable level. Furthermore, the correlation matrix review did not reveal extremely strong connections between the variables, and therefore it can be concluded that the multicollinearity problem does not have sufficient power in the model to have a significant effect on the coefficients of various variables.
Table 8. VIF estimates

\begin{tabular}{|c|c|c|}
\hline Variable & FE & Pooled \\
\hline Size & 6,36 & 1,26 \\
\hline Tang & 5,77 & 2,15 \\
\hline GrOpp & 3,18 & 1,56 \\
\hline TaxSh & 3,16 & 1,04 \\
\hline Prof & 3,01 & 1,40 \\
\hline NDTS & 2,95 & 1,40 \\
\hline LProf & 1,90 & 1,10 \\
\hline IntAmort & 1,71 & 1,14 \\
\hline $\mathrm{MtB}$ & 1,69 & 1,37 \\
\hline $\mathrm{RnD}$ & 1,69 & 1,13 \\
\hline Mean VIF & 3,14 & 1,33 \\
\hline
\end{tabular}

Source: drafted by the author. 
The second potential issue of the model may be the error variance dependence on the observation number or heteroscedasticity available within it. To test the assumption that this problem exists, we will run a generalized Wald test (Appendix 5). The null hypothesis of the test is that the error variance does not depend on the observation, but the test result indicates that the null hypothesis is rejected. Therefore, heteroscedasticity may be seen to exist within the fixed effects model.

Finally, a check is performed on the model for the existence of autocorrelation. In general, there are two types of autocorrelation - serial or spatial. The second (spatial) type of autocorrelation is inherent in those models where the number of years covered in the sample exceeds the number of companies. For the data studied in this article, the opposite is the case, because the number of analyzed companies is more than 100 times higher than the length of the time period. Therefore, based on the nature of the data, we assume that only serial autocorrelation may exist in the model, the essence of which is that the observational errors for one firm over different periods may be related to each other.

As such, a test will be performed on the fixed effects model for serial autocorrelation, using the Wooldridge test for this purpose (Appendix 6). Based on the test results, the null hypothesis of the absence of a link between observational errors is rejected, thus revealing the existence of autocorrelation in the model under consideration.

Thus, the result of the study of the fixed effects model is the identification of the heteroscedasticity and serial autocorrelation problems, and therefore further adjustment of the model will be made.

To perform the adjustment, the following set of tools will be applied: White standard errors (heteroscedasticity measurement), Roger's standard errors (heteroscedasticity and autocorrelation measurement), and a non-parametric covariance matrix estimation ${ }^{4}$ (also heteroscedasticity and autocorrelation measurement). The results given in Appendix 7 indicate that, regardless of the model having been given various adjustments, the coefficients preceding all variables retain their signs and levels of significance. The result is that the original fixed effects model, given in Table 7, is applicable for the analysis of the capital structure determinants, since all the identified problems do not have a significant impact on the results of the estimates obtained. Furthermore, it is worth noting that, due to some peculiarities, for example, the availability of data gaps in the sample, the described procedures for detecting errors and making adjustments cannot be fully applied to the two other models - pooled and random effects models, and therefore we can assume that the coefficient estimates given in Table 7 are not distorted.

The potential problem of endogeneity should be also briefly discussed. Within this study, testing for the presence of such a problem is difficult due to the complexity in establishing an appropriate tool for this. However, it is worth mentioning that one of the possible causes of endogeneity may be simultaneity when it is unclear whether the explanatory variable influences the dependent variable or if there is an inverse relationship. As part of studying the capital structure of innovative companies, the following question may arise: does innovation activity affect the debt level, or, conversely, does the company make decisions on investments in research and development based on the current level of borrowing? The answer to this question is provided in the work of E. Bartoloni [20], where the Granger causality test is conducted. The result of this test is evidence of the fact that financial leverage is the dependent variable. This suggests the absence of the problem of endogeneity, which is also pertinent in the case of the present study.

\section{Analysis of model test results}

Having made a series of regression models, and also having got an idea of the role of various errors in the calculation of coefficients of the determinants under study, we will proceed directly to the analysis of the results obtained (given in Table 7).

We are going to start with the first two variables (Prof and LProf), which are responsible for the current and lag indicators of the company's profitability, respectively. The negative sign of both coefficients is maintained for all specifications of the model, and the Prof variable is significant at the $1 \%$ level in the pooled regression and fixed effects model. This result coincides with most of the previously reviewed studies and has absolute coefficient values, which are quite close to the estimates obtained, for example, in the work of P. Castro and M. Tascon [22]. The resulting sign of the variables means that more profitable companies tend to generate a smaller amount of debt. This coincides with the expected effect of the variables and supports the pecking order theory. A negative coefficient of a lagging profit indicator means that companies also tend to rely on last year's results of their activities, since this makes it possible to manage expectations about current results.

The Size variable shows a steady positive impact on the amount of debt, which corresponds to the trade-off theory. There are at least two explanations for this effect. First, larger firms are associated with a lower bankruptcy probability, and therefore borrowing costs are reduced [2]. Second, the larger the market share of the firm, the lower the information asymmetry costs associated with its activities, which also entails giving it access to more favorable loan terms. Both of these effects are particularly relevant for innovative companies, so the estimates of the coefficients of the variable are positive.

The next major variable, Tang, also has a sustained positive effect on debt levels. The obtained estimates of the 
coefficients correspond to the trade-off theory, since with an increase in the proportion of tangible assets, the loan security base grows, increasing the maximum potential amount of debt and improving the conditions for its formation. As expected, this effect will have a strong influence on innovative companies due to the fact that the level of their tangible assets is noticeably lower compared to non-technological firms.

The last variable included in the basic model is $\mathrm{MtB}$, and its coefficient has a positive sign at the $1 \%$ level of significance regardless of the model specification. This result means that the growth potential, measured as the market and book value ratio of the company's capital, has a positive effect on the firm's motivation to borrow. This result is contrary to expectations, as well as to most of the work that includes a similar variable in the analysis. It can be assumed that this effect is due to the lack of internal funds in companies for financing their own growth. However, it is important to note that the influence of this factor is extremely weak with all the model specifications, so it is possible that although the effect of this factor is sustainable, it does not play an important role in the decision making process on the formation of an additional debt unit.

Let us proceed to the analysis of the coefficients of the remaining variables, the first of which is the growth potential GrOpp, measured as the ratio of capital costs to total assets. This variable has a negative effect on the leverage value, (which coincides with the assumptions of this study), but the variable is not significant. The explanation is that capital costs are the capital that companies use to acquire or upgrade various kinds of physical assets that do not play a fundamental role in the activities of innovative companies. The level of tangible assets in high-tech companies is relatively low, so the variable under review is not associated with an amount of growth potential which is sufficient to influence the amount of debt.

The $\mathrm{RnD}$ variable is the latest proxy to reflect the development potential of an innovative firm and, within the framework of the models under consideration, has a significant negative impact on the pooled regression and the random effects model. This effect is consistent with this study's initial assumptions, and is also supported by the conclusions of a number of works [13; 31] Hyytinen, Pajarinen, 2005]. Thus, it can be stated that the R\&D costs, acting as an indicator of the company's development potential, in fact reduce the motivation to borrow due to the consequential costs of underinvestment in the future.

The effect of the tax shield (TaxSh) also coincides with the assumption made in the methodological part of this study, in that in all three model specifications this variable has a positive effect on the size of the financial leverage. It is worth noting, however, that the variable is significant only with the Pooled model at the 5\% level, which indicates that the tax shield cannot be described as a crucial factor; rather, it is relegated to a minor role.
The variable responsible for the company's age (Age) shows an extremely unexpected effect, whereby the older the company becomes, the less it tends to borrow. This effect can be explained in two ways. First, age is positively correlated with the company's profitability, therefore, it can be assumed that more mature firms will need to borrow less. Second, it is probable that for the specific companies under review, the actual details of their commercial and other activities imply that lenders would be generally more afraid to loan, despite the long-term existence of the firm.

The coefficient of the non-debt tax shield (NDTS) has a negative sign, which corresponds to the assumption that the benefits from asset amortization play a significant role, reducing the motivation to use debt. This variable is especially important for innovative companies, since the PP\&E depreciation amount is added to the amount of fixed assets depreciation.

The final variable examined at this stage of the study is the proportion of the intangible assets amortization in the total amortization amount (IntAmort). Despite the assumption of a negative effect, the actual coefficient has a positive sign and, moreover, it is significant for all the model specifications considered. This variable is a proxy for the level of intangible assets in the company, therefore, guided by the pecking order theory, we may assume that the identified direction of effect means that an increase in the proportion of intangible assets leads to a need for external funding. Securing intangible assets with the use of equity can be risky due to the nature of the asset category, therefore, companies may need external funds.

The final results for all significant variables are given in Table 9.

At this stage of the study, we have obtained an understanding of the role of various determinants in the formation of the company's capital structure, but this is not enough to make final conclusions. First, it is necessary to check the significance of the country factor, and, second, to test the results obtained for stability.

As described in the methodological section above, the factor of the company's location in the territory of a particular country from the BRICS list will be taken into account by including a set of dummy variables in the analysis. However, this approach faces a problem related to the need to determine the parameters of the basic variable, that is, the regression results may be sensitive to the definition of the basis. To address this problem, the following approach will be used. Five independent regressions will be performed, alternately using each country as the base variable, and the Pooled model will be used. This choice of model was made for two reasons: the best identified model - FE does not take into account dummy variables, and although the random effects model is technically better than the pooled regression, it still has some flaws in application in such circumstances (for example, the RE-model makes the coefficient of the Prof variable insignificant). 
Table 9. Significant results of the regression model evaluation.

$\begin{array}{lccc}\text { Variables } & \text { Pooled } & \text { FE } & \text { RE } \\ \text { Prof } & -0.226^{* * *} & -0.0799^{* * *} & - \\ \text { LProf } & -0.0436^{* * *} & & - \\ \text { Size } & 0.0180^{* * *} & 0.0340^{* * *} & 0.0242^{* * *} \\ \text { Tang } & 0.333^{* * *} & 0.226^{* * *} & 0.266^{* * *} \\ \text { MtB } & 0.000455^{* * *} & 0.000423^{* * *} & 0.000406^{* * *} \\ \text { RnD } & -0.182^{* * *} & - & -0.0512^{*} \\ \text { TaxSh } & 0.0382^{* *} & - & - \\ \text { Age } & - & -0.0292^{* * *} & - \\ \text { NDTS } & -0.368^{* * *} & - & - \\ \text { IntAmort } & 0.0212^{*} & 0.0328^{* * *} & 0.0255^{* *} \\ \text { Constant } & - & - & -0.0422^{* *} \\ \text { Observations } & \mathbf{4 , 1 2 0} & \mathbf{4 , 1 2 0} & \mathbf{4 , 1 2 0} \\ \mathbf{R}^{2} & \mathbf{0 . 2 1 3} & \mathbf{0 . 1 7 4} & \mathbf{0 . 1 5 7} \\ { }^{*} \mathrm{p}<0.1 ;{ }^{* *} \mathrm{p}<0.05 ; * * * \mathrm{p}<0.01 . & & & \end{array}$

Source: drafted by the author.

Table 10. Evaluation results of the model with country-dummy inclusion

\begin{tabular}{|c|c|c|c|c|c|}
\hline Variables & Brazil & Russia & India & China & RSA \\
\hline Prof & $-0.222^{\star * *}$ & $-0.222^{\star * \star}$ & $-0.222^{\star * \star}$ & $-0.222^{\star * \star}$ & $-0.222^{\star \star *}$ \\
\hline LProf & $-0.0486^{* * *}$ & $-0.0486^{* * *}$ & $-0.0486^{* * *}$ & $-0.0486^{* * *}$ & $-0.0486^{* * *}$ \\
\hline Size & $0.0180^{\star * \star}$ & $0.0180^{\star * \star}$ & $0.0180^{* * *}$ & $0.0180^{* * \star}$ & $0.0180^{\star \star \star}$ \\
\hline Tang & $0.356^{* * *}$ & $0.356^{* * *}$ & $0.356^{* * *}$ & $0.356^{* * \star}$ & $0.356^{* * *}$ \\
\hline $\mathrm{MtB}$ & $0.000473^{* * *}$ & $0.000473^{\star * \star}$ & $0.000473^{\star * *}$ & $0.000473^{\star * \star}$ & $0.000473^{\star * *}$ \\
\hline GrOpp & -0.00396 & -0.00396 & -0.00396 & -0.00396 & -0.00396 \\
\hline $\mathrm{RnD}$ & $-0.166^{\star * *}$ & $-0.166^{\star * \star}$ & $-0.166^{\star * \star}$ & $-0.166^{\star * \star}$ & $-0.166^{\star * \star}$ \\
\hline TaxSh & $0.0370^{* *}$ & $0.0370^{* *}$ & $0.0370^{* \star}$ & $0.0370^{\star *}$ & $0.0370^{\star \star}$ \\
\hline Age & -0.00322 & -0.00322 & -0.00322 & -0.00322 & -0.00322 \\
\hline NDTS & $-0.478^{\star * *}$ & $-0.478^{\star \star \star}$ & $-0.478^{\star * \star}$ & $-0.478^{\star * \star}$ & $-0.478^{\star \star \star}$ \\
\hline IntAmort & $0.0204^{\star}$ & $0.0204^{\star}$ & $0.0204^{\star}$ & $0.0204^{\star}$ & $0.0204^{\star}$ \\
\hline Brazil & & $0.189^{* * *}$ & $0.261^{\star * *}$ & $0.228^{\star * \star}$ & $0.189^{\star * \star}$ \\
\hline Russia & $-0.189^{* * *}$ & & $0.0715^{\star \star}$ & 0.0391 & -0.000520 \\
\hline India & $-0.261^{\star * \star}$ & $-0.0715^{\star \star}$ & & $-0.0324^{\star \star \star}$ & $-0.0720^{\star * \star}$ \\
\hline China & $-0.228^{\star * \star}$ & -0.0391 & $0.0324^{\star * \star}$ & & $-0.0396^{\star}$ \\
\hline SAR & $-0.189^{* * *}$ & 0.000520 & $0.0720^{\star \star \star}$ & $0.0396^{\star}$ & \\
\hline Constant & $0.226^{* * *}$ & 0.0373 & $-0.0342^{\star}$ & -0.00175 & 0.0379 \\
\hline Observations & 4120 & 4120 & 4120 & 4120 & 4120 \\
\hline $\mathbf{R}^{2}$ & 0.25 & 0.25 & 0.25 & 0.25 & 0.25 \\
\hline
\end{tabular}

Source: drafted by the author. 
The results of the country dummy variable inclusion in the model are presented in Table 10 (the countries taken as the base are indicated at the top). Based on the obtained estimates of the coefficients, a number of conclusions can be drawn. First, the coefficients for the main variables do not change depending on the base country. Second, the values of the coefficients are slightly different from the estimates obtained earlier (see Table 7), retaining all signs and levels of significance. Third, the significance of dummy variables strongly depends on the chosen basis. These three observations suggest that the inclusion of the country factor in the model does not make sense. To verify this assumption, we have performed a test on the hypothesis of an insignificant difference from zero in the $q$-coefficients of the regression equation, where $q$ is the number of dummies denoting countries (four), and the ordinary Pooled model will be used as an equation with restrictions. The result of the test was that the inclusion of dummy variables in the analysis was justified.

Thus, the country factor does have an effect on the capital structure of the companies under review. A more thorough analysis allows us to conclude that countries are in the following descending order regarding the strength of the positive effect on the amount of debt: Brazil, South Africa, Russia, China, India. However, at the same time, it can be noted that the effect of this factor is not too strong, because the adjustment made by the country factor only slightly changes the coefficients of the variables of the main equation.

Having developed and tested the final model, it will hereby be interpreted in terms of the implementation of the hypotheses of this article, starting with hypothesis 4 , which states that the growth potential and intangible assets of the company negatively affect the value of its debt. Based on the results obtained, it can be considered that the hypothesis is only partially confirmed. On the one hand, the proxy variable for the proportion of intangible assets - IntAmort - has a steady positive effect on leverage. On the other hand, two out of the three growth potential proxies (GrOpp, $\mathrm{RnD}$ ) have negative signs, and the only factor with a positive impact $(\mathrm{MtB})$ has a very weak effect on the amount of borrowing. Thus, the part of the hypothesis regarding intangible assets is not consistent with the results obtained, while the part concerning growth potential appears to be confirmed.

As for hypothesis 3, it also cannot be unambiguously confirmed. Estimates of the coefficients of Prof, Age and IntAmort variables confirm the adhesion of the companies under review to the pecking order theory. However, estimates of Tang, Size and NDTS variables are consistent with the trade-off theory. Based on this correlation of variables, it is difficult to conclude which theory more accurately describes the behavior of innovative companies of the BRICS countries. In this regard it may be stipulated that a "classic" result has been obtained, whereby both theories play an important role. While the hypothesis has found support it has not been demonstrated obviously enough to get confirmation.

\section{Conclusion}

This article identified the main features of the capital structure of innovative companies from BRICS countries, as well as the significant determinants of that capital structure and the directions of their effect. To achieve this goal, an analysis which includes three main stages was carried out.

First, on the basis of theoretical prerequisites, as well as the work of a large number of various authors, the main features of innovative companies influencing the structure of their capital were identified. These features include the existence of the information asymmetry costs associated with the specificity and uniqueness of the activities of innovative companies, the presence of high growth potential generated by the existence of network effects, the high applicability of innovation, and the low marginal and transport costs associated with these companies. Furthermore, it was noted that intangible assets had a significantly larger proportion in the asset structure of high-tech companies than in other firms.

Second, a comparative analysis of high-tech and non-innovative companies was performed. Comparisons between them were made for parameters such as profitability, size, the proportion of tangible assets, and growth potential. The result of this analysis was that the hypothesis of the need to explain the capital structure of companies varying in their level of innovativeness with the use of different models was confirmed. Moreover, it was shown that the level of borrowing of innovative firms is at a lower level.

Finally, at the third stage, a detailed analysis was performed of innovative companies using a broad selection of variables. The results obtained at this stage of work made it possible to come to several conclusions. First, the coefficients of the estimated variables confirmed the significance of both the pecking order theory and the trade-off theory, thereby not providing an option to fully confirm one of the hypotheses of the study. Second, it was confirmed that the proportion of intangible assets in the company has a multidirectional effect on the amount of debt, which also contradicts one of the hypotheses of this paper. However, it was proven that growth potential is a significant factor which has a predominantly negative effect on the level of an innovative company's financial leverage.

The model was also tested for errors such as multicollinearity, autocorrelation, and heteroscedasticity, which showed that the results of the study were not distorted. Furthermore, with the use of dummy variables, the country factor was taken into account, which, although appearing to be significant, did not show a strong effect on the amount of companies' debt. In addition, a separate analysis was performed for companies with different levels of growth potential, which confirmed the importance of growth potential as determinants of the capital structure of innovative companies.

Finally, it should be noted that by implementing methods such as the change of the dependent variable, and a reduc- 
tion in the number of companies studied, it was possible to draw positive conclusions about the sustainability of the results obtained in the study.

In general, the outcome of this article may be regarded as obtaining an understanding of those determinants that have a significant effect on the capital structure of innovative companies of the BRICS countries. The results obtained indicate that these companies use relatively little borrowed capital with high growth potential, which indicates the need to overcome the information asymmetry challenge in order to increase not only the growth rates of individual companies, but also the economy as a whole.

\section{References}

1. Rajan G.R., Zingales L. What do we know about capital structure? Some evidence from international data. The Journal of Finance. 1995;50(5):1421-1460. DOI: $10.2307 / 2329322$

2. Titman S., Wessels R. The determinants of capital structure choice. The Journal of Finance. 1988;43(1):119. DOI: $10.2307 / 2328319$

3. Adedeji A. A cross-sectional test of pecking order hypothesis against static trade-off theory on UK. SSRN Electronic Journal. 2002. DOI: 10.2139/ ssrn.302827

4. Booth L., Aivazian V., Demirguk-Kunt A., Maksimovic V. Capital structures in developing countries. The Journal of Finance. 2001;56(1):87-130. DOI: $10.1111 / 0022-1082.00320$

5. Komera S., Lukose J. Capital structure choice, information asymmetry, and debt capacity: Evidence from India. Journal of Economics and Finance. 2015;39(4):807-823. DOI: 10.1007/s12197-014-92853

6. Sánchez-Vidal J., Martín-Ugedo J. Financing preferences of Spanish firms: Evidence on the pecking order theory. Review of Quantitative Finance and Accounting. 2005;25(4):341-355. DOI: 10.1007/ s11156-005-5459-6

7. Köksal B., Orman C. Determinants of capital structure: Evidence from a major developing economy. Small Business Economics. 2015;44(2):255282. DOI: $10.1007 / \mathrm{s} 11187-014-9597-\mathrm{X}$

8. Matemilola B.T., Ahmad R. Debt financing and importance of fixed assets and goodwill assets as collateral: Dynamic panel evidence. Journal of Business Economics \& Management. 2015;16(2):407421. DOI: $10.3846 / 16111699.2013 .772916$

9. Bradley M., Jarrell G.A., Kim E.H. On the existence of optimal capital structure: Theory and evidence. The Journal of Finance. 1984;39(3):857-878. DOI: 10.1111/j.1540-6261.1984.tb03680.x
10. Talberg M., Winge C., Frydenberg S., Westgaard S. Capital structure across industries. International Journal of the Economics of Business. 2008;15(2):181200. DOI: $10.1080 / 13571510802134304$

11. Phillips R.W. Innovation and firm performance in Australian manufacturing. Melbourne: Industry Commission; 1997.87 p.

12. Hogan T., Hutson E. Capital structure in new technology-based firms: Evidence from the Irish software sector. Global Finance Journal. 2005;15(3):369-387. DOI: 10.1016/j.gfj.2004.12.001

13. Hyytinen A., Pajarinen M. Financing of technologyintensive small businesses: Some evidence on the uniqueness of the ICT sector. Information Economics and Policy. 2005;17(1):115-132. DOI: 10.1016/j. infoecopol.2004.03.005

14. Martin S., Scott J.T. The nature of innovation market failure and the design of public support for private innovation. Research Policy. 2000;29(4-5):437-447. DOI: 10.1016/S0048-7333(99)00084-0

15. Myers S.C. Determinants of corporate borrowing. Journal of Financial Economics. 1977;5(2):147-175. 10.1016/0304-405X(77)90015-0

16. Bruinshoofd W.A., De Haan L. Is the negative relation between leverage and historical market-to-book specific to US and information and communication technology firms? International Review of Finance. 2011;11(2):227-243. DOI: 10.1111/j.14682443.2010.01116.x

17. Brierley P. The financing of technology-based small firms: A review of the literature. Bank of England Quarterly Bulletin. 2001;41(1):64-83.

18. Myers S.C. The capital structure puzzle. The Journal of Finance. 1984;39(3):574-592. DOI: 10.1111/j.15406261.1984.tb03646.x

19. Hall B.H., Lerner J. The financing of R\&D and innovation. In: Hall B.H., Rosenberg N., eds. Handbook of the economics of innovation. Vol. 1. Amsterdam: Elsevier; 2010:610-638.

20. Bartoloni E. Capital structure and innovation: Causality and determinants. Empirica. 2013;40(1):111-151. DOI: 10.1007/s10663-0119179-y

21. Michaelas N., Chittenden F., Poutziouris P. Financial policy and capital structure choice in UK SMEs: Empirical evidence from company panel data. Small Business Economics. 1999;12(2):113-130. DOI: 10.1023/A:1008010724051

22. Castro P., Tascón M., Amor-Tapia B. Dynamic analysis of the capital structure in technological firms based on their life cycle stages. Spanish Journal of Finance and Accounting. 2015;44(4):458-486. DOI: $10.1080 / 02102412.2015 .1088202$ 
23. Aghion P., Bond S., Klemm A., Marinescu I. Technology and financial structure: Are innovative firms different? Journal of the European Economic Association. 2004;2(2-3):277-288. DOI: $10.1162 / 154247604323067989$

24. Francis J., Schipper K. Have financial statements lost their relevance? Journal of Accounting Research. 1999;37(2):319-352. DOI: 10.2307/2491412

25. Kwon S.S., Yin Q.J., Han J. The effect of differential accounting conservatism on the "over-valuation" of high-tech firms relative to low-tech firms. Review of Quantitative Finance and Accounting. 2006;27(2):143173. DOI: $10.1007 /$ s11156-006-8794-3

26. Ivashkovskaya I.V., Solntseva M.S. Capital structure in Russian companies as a strategic decision. Vestnik Sankt-Peterburgskogo universiteta. Menedzhment = Vestnik of Saint Petersburg University. Management Series. 2008;(3):3-32. (In Russ.).

27. Chen J.J. Determinants of capital structure of Chinese-listed companies. Journal of Business Research. 2004;57(12):1341-1351. DOI: 10.1016/ S0148-2963(03)00070-5
28. Frank M.Z., Goyal V.K. Capital structure decisions: Which factors are reliably important? Financial Management. 2009;38(1):1-37. DOI: 10.1111/j.1755053X.2009.01026.x

29. Schäfer D., Werwatz A., Zimmermann V. The determinants of debt and (private) equity financing: The case of young, innovative SMEs from Germany. Industry and Innovation. 2004;11(3):225-248. DOI: $10.1080 / 1366271042000265393$

30. Fama E.F., French K.R. Testing trade-off and pecking order predictions about dividends and debt. The Review of Financial Studies. 2002;15(1):1-33. DOI: $10.1093 / \mathrm{rfs} / 15.1 .1$

31. Clausen S., Hirth S. Measuring the value of intangibles. Journal of Corporate Finance. 2016;40:110-127. DOI: 10.1016/j.jcorpfin.2016.07.012 


\section{Appendices}

Appendix 1. SIC codes used in the study for determination of innovative companies

\begin{tabular}{|c|c|c|}
\hline SIC & Industry & $\begin{array}{l}\text { Number of } \\
\text { companies }\end{array}$ \\
\hline 283 & Drugs & 238 \\
\hline 357 & Computer and office equipment & 37 \\
\hline 361 & Electric transmission and distribution equipment & 40 \\
\hline 362 & Electrical industrial apparatus & 34 \\
\hline 363 & Household appliances & 40 \\
\hline 364 & Electric lighting and wiring equipment & 20 \\
\hline 365 & Household audio and video equipment and audio recordings & 22 \\
\hline 366 & Communication equipment & 68 \\
\hline 367 & Electronic components and accessories & 172 \\
\hline 369 & Miscellaneous electrical machinery, equipment, and supplies & 23 \\
\hline 481 & Telephone communications & 19 \\
\hline 737 & Computer programming, data processing, and other computer related services & 220 \\
\hline 873 & Research, development, and testing services & 6 \\
\hline
\end{tabular}

Appendix 2. SIC codes used in the study for determination of non-innovative companies

\begin{tabular}{|c|c|c|}
\hline SIC & Industry & $\begin{array}{l}\text { Number of } \\
\text { observations }\end{array}$ \\
\hline 160 & Heavy construction other than building construction - contractors & 54 \\
\hline 170 & Construction - special trade contractors & 10 \\
\hline 202 & Dairy products & 13 \\
\hline 220 & Textile mill products & 74 \\
\hline 240 & Lumber and wood products, except furniture & 38 \\
\hline 260 & Paper and allied products & 58 \\
\hline 308 & Miscellaneous plastics products & 49 \\
\hline 324 & Cement, hydraulic & 31 \\
\hline 331 & Steel works, blast furnaces, and rolling and finishing mills & 78 \\
\hline 356 & General industrial machinery and equipment & 59 \\
\hline 371 & Motor vehicles and motor vehicle equipment & 120 \\
\hline 401 & Railroads & 7 \\
\hline 421 & Trucking and courier services, except air & 6 \\
\hline 440 & Water transportation & 37 \\
\hline 451 & Air transportation, scheduled, and air courier services & 13 \\
\hline 541 & Grocery stores & 12 \\
\hline
\end{tabular}


Appendix 3. Result of Breusch-Pagan test

Breusch and Pagan Lagrangian multiplier test for random effects

$\operatorname{Debt}[\mathrm{id}, \mathrm{t}]=\mathrm{Xb}+\mathrm{u}[\mathrm{id}]+\mathrm{e}[\mathrm{id}, \mathrm{t}]$.

Estimated results:

$\begin{array}{rcc} & \text { Var } & \text { sd }=\text { sqrt(Var) } \\ \text { Debt } & 0,0189 & 0,1377 \\ \mathrm{e} & 0,0051 & 0,0718 \\ \mathrm{u} & 0,0104 & 0,1023\end{array}$

Test: $\operatorname{Var}(\mathrm{u})=0$

chibar2 $=0.0000$

Prob $>$ chibar $2(01)=3528.28$

Appendix 4. Result of Hausman test

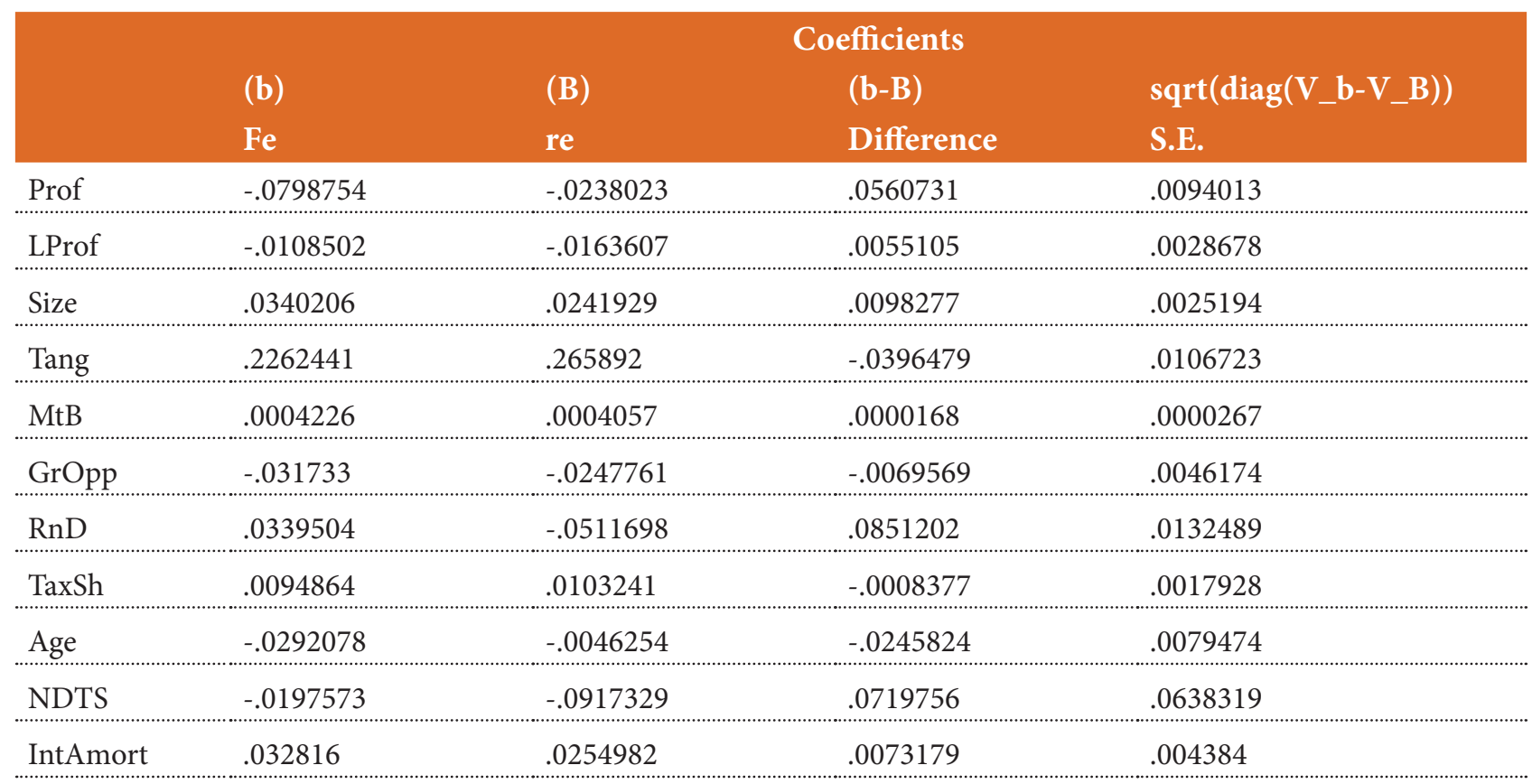

$\mathrm{b}=$ consistent under Ho and Ha; obtained from xtreg

$\mathrm{B}=$ inconsistent under Ha, efficient under Ho; obtained from xtreg.

Test:H0:difference in coefficients not systematic

$\operatorname{chi} 2(11) \quad=(\mathrm{b}-\mathrm{B})^{\prime}\left[\left(\mathrm{V}_{-} \mathrm{b}_{-\mathrm{V}} \mathrm{B}\right)^{\wedge}(-1)\right](\mathrm{b}-\mathrm{B})$

$=147.89$

Prob $>$ chi $2 \quad=0.0000$ 
Appendix 5. Result of Wald test

Modified Wald test for groupwise heteroscedasticity in fixed effect regression model

H0: sigma(i)^2 $=\operatorname{sigma}^{\wedge} 2$ for all $\mathrm{i}$

chi2 $(734)=8.3 e+33$

Prob $>$ chi $2=0.0000$

Appendix 6. Result of Wooldridge test

Wooldridge test for autocorrelation in panel data

H0: no first-order autocorrelation

$\mathrm{F}(1.673)=2.432$

Prob $>\mathrm{F}=0.0000$

Appendix 7. Results of regression adjustments

\begin{tabular}{|c|c|c|c|c|}
\hline Variable & $\mathrm{fe}$ & fe_robust & fe_cluster & fe_scc \\
\hline Prof & $-.07987544^{\star * \star}$ & $-.07987544^{\star}$ & $-.07987544^{\star}$ & $-.07987544^{\star *}$ \\
\hline LProf & -.01085017 & -.01085017 & -.01085017 & $-.01085017^{\star}$ \\
\hline Size & $.03402063^{\star * *}$ & $.03402063^{* * *}$ & $.03402063^{* * *}$ & $.03402063^{\star * *}$ \\
\hline Tang & $.22624408^{\star * \star}$ & $.22624408^{* * *}$ & $.22624408^{* * *}$ & $.22624408^{\star * *}$ \\
\hline $\mathrm{MtB}$ & $.00042256^{\star * *}$ & $.00042256^{* * *}$ & $.00042256^{* * *}$ & $.00042256^{* *}$ \\
\hline GrOpp & -.03173298 & -.03173298 & -.03173298 & -.03173298 \\
\hline $\mathrm{RnD}$ & .03395039 & .03395039 & .03395039 & .03395039 \\
\hline TaxSh & .00948639 & .00948639 & .00948639 & .00948639 \\
\hline Age & $-.02920779^{* * *}$ & $-.02920779^{\star}$ & $-.02920779^{*}$ & $-.02920779^{* * *}$ \\
\hline NDTS & -.01975729 & -.01975729 & -.01975729 & -.01975729 \\
\hline IntAmort & $.03281604^{\star * *}$ & $.03281604^{* *}$ & $.03281604^{* *}$ & $.03281604^{* * *}$ \\
\hline _cons & -.03311476 & -.03311476 & -.03311476 & -.03311476 \\
\hline
\end{tabular}

Appendix 8. Results of regressions with changed dependent variable

\begin{tabular}{|c|c|c|c|}
\hline Variable & pool_Ltd & fe_Ltd & re_Ltd \\
\hline Prof & $-.02866937^{\star \star}$ & -.01752809 & -.01079245 \\
\hline LProf & -.00052142 & .00562857 & .00339258 \\
\hline Size & $.01026377^{\star \star *}$ & $.02048328^{\star * *}$ & $.01295639^{* * *}$ \\
\hline Tang & $.13363339^{* * *}$ & $.08600627^{\star * *}$ & $.10683105^{\star \star \star}$ \\
\hline $\mathrm{MtB}$ & $.00012231^{\star *}$ & $.00012397^{\star *}$ & $.00008992^{\star *}$ \\
\hline GrOpp & $.04782855^{\star *}$ & $.04367526^{* *}$ & $.0475339^{\star * \star}$ \\
\hline $\mathrm{RnD}$ & $.02562191^{\star}$ & $.04582694^{\star *}$ & .02077422 \\
\hline TaxSh & $.03046298^{\star * *}$ & $.01329726^{*}$ & $.01616565^{\star \star}$ \\
\hline Age & -.00143026 & $-.02453392^{\star * *}$ & $-.00543344^{\star}$ \\
\hline NDTS & $-.1575522^{* * *}$ & -.09913022 & $-.10966824^{\star}$ \\
\hline IntAmort & $.03194014^{\star * *}$ & $.02823245^{\star * *}$ & $.02693099^{* * *}$ \\
\hline _cons & $-.05106746^{\star * *}$ & $-.03347401^{\star *}$ & $-.04804811^{\star * *}$ \\
\hline
\end{tabular}


Appendix 9. Results of regressions on curtailed sample

\begin{tabular}{|c|c|c|c|}
\hline Variable & pool & $\mathrm{fe}$ & re \\
\hline Prof & $-.27531357^{\star * *}$ & $.04688933^{\star}$ & $-6.267 e-06$ \\
\hline LProf & -.0065659 & -.00376311 & -.00420911 \\
\hline Size & $.01887831^{\star * *}$ & $.03116822^{* * *}$ & $.02274216^{\star * *}$ \\
\hline Tang & $.38639663^{\star * \star}$ & $.21919802^{* * *}$ & $.2694406^{\star * *}$ \\
\hline $\mathrm{MtB}$ & $.00052568^{\star \star *}$ & $.00043115^{\star * *}$ & $.00042012^{* * *}$ \\
\hline GrOpp & -.01047027 & $-.0537047^{\star}$ & -.04717004 \\
\hline $\mathrm{RnD}$ & $-.22953652^{* * *}$ & .02536948 & $-.0582564^{*}$ \\
\hline TaxSh & .02528162 & .00492573 & .00433938 \\
\hline Age & .00008496 & $-.02299369^{* *}$ & -.00050959 \\
\hline NDTS & $-.63214473^{\star * *}$ & -.05613808 & -.13884604 \\
\hline IntAmort & $.03743833^{\star * *}$ & $.03330137^{\star *}$ & $.02600231^{\star *}$ \\
\hline _cons & -.01258025 & -.02455333 & $-.03829832^{* *}$ \\
\hline
\end{tabular}

